\title{
Assessment of Nephrotoxicity and Histopathological Lesions of Albino Rats Exposure to DD-Force and Baygon Insecticides.
}

\author{
Evaluación de la nefrotoxicidad y lesiones histopatológicas tras la exposición \\ de ratas Albino a los insecticidas DD-Force y Baygon. \\ Nwankwo Victor Omoha', Uraku Anayo Joseph ${ }^{2}$, Famurewa Ademola Clement ${ }^{3}$ \& Uraku Oluchi Helen. ${ }^{2}$
}

\begin{abstract}
Nwankwo, V.O., Uraku, A.J., Famurewa, A.C. \& Uraku, O.H. Assessment of Nephrotoxicity and Histopathological Lesions of Albino Rats Exposure to DD-Force and Baygon Insecticides. Int. J. Med. Surg. Sci., 4(4):1251-1258, 2017.

SUMMARY: Although studies suggest adverse effects of pesticides, human exposure to insecticides in homes is increasing and reports on their health effects are limited. The study investigated nephrotoxic effects of organo phosphate and carbamate insecticides, DD-Force and Baygon, in albino rats. Forty-five albino rats divided into groups were exposed to DD-Force (dichlorvos) or Baygon (propoxur) indoor insecticidein wooden boxes in separate exposure duration of 1, 2, 3 and 4 hours/day for 14 consecutive days. Serum and kidney tissue obtained after sacrifice were used to determine markers of renal damage and histopathological analysis, respectively. Exposure of rats to the insecticides showed duration-dependent significant increases $(p<0.05)$ in serum levels of urea, uric acid and creatinine compared to control. However, rats exposed to DD-Force insecticide induced significantly higher levels of urea, uric acid and creatinine compared to Baygon $(p<0.05)$. Histopathological lesions were observed in rats exposed to the insecticides, particularly in the exposure duration of 3 or 4 hours/day. These findings suggest that acute exposure to DD-Force and Baygonis nephrotoxic and may induce renal damage in rats.
\end{abstract}

KEYWORDS: insecticides; DD-Force; Baygon, exposure; renal damage.

\section{INTRODUCCIÓN}

Human exposure to environmental toxicants is on the increase worldwide and is a major public health challenge. Pollutants from agricultural sector such as pesticides are of crucial concern in food safety and potential hazard for aquatic life due to accumulation of many chemicals in soil and water bodies (Tsitsimpikoua et al., 2013, Begum 2004). Although, chemical agents in agricultural pesticides and their potential deleterious effects on public health have received abundant attention (Banerje 1999), household insecticides are latent sources of toxicity and limited data are available on them in the existing literature.

Household insecticides have played a vital role in homes and in control of public health pests (Rekha and Sajad, 2013). However, the health risks associated with residual insecticide in air and on surfaces in residences have been indicated in some studies (Tsitsimpikoua et al.; Begum; Rekha \& Sajad). Baygon super insecticide is used in homes against mosquitoes, fleas, black flies, and cockroaches (Ngoula et al., 2007). In the tropical and subtropical nations, malaria is a public health problem. Malaria infection is strikingly endemic in Nigeria with prevalent rate ranging from $27 \%$ to $50 \%$ in children aged 6 to 59 months (Kolawole and Asaolu, 2016). Baygon super insecticide is a common insect repellant in Nigeria usually sprayed indoors particularly to kill nocturnally active insects, including mosquitoes. It is composed of well-known insecticide chemicals; $1 \%$ proporxur (a carbamate), 1\% dichlorvos (an organophosphate) and $0.04 \%$ cyfluthrin (a synthetic pyrethroid) (Bohmont, 1990), which are associated with liver and kidney damage (Yassin and Al-Shanti, 2015, Institóris, 2002), reproductive abnormalities (Ngoula et al.), oxidative stress and genotoxic effect (Tsitsimpikoua et al.).

However, the synergistic effect of these chemical agents in Baygon super insecticide is sparsely reported in systematic investigations. Such exposures are of great concern, especially since exposure to insecticides has been shown to alter lipid metabolism and cause liver damage in rats (Aldana, 2001; Tsitsimpikoua et al.).

\footnotetext{
1. Department of Biotechnology, Ebonyi State University, PMB 053 Abakaliki, Ebonyi State, Nigeria.

2. Department of Biochemistry, Ebonyi State University, PMB 053 Abakaliki, Ebonyi State, Nigeria.

3. Department of Medical Biochemistry, Federal University Ndufu-Alike, Ikwo, Ebonyi State, Nigeria.
} 
Nwankwo, V. O., Uraku, A. J., Famurewa, A. C. \& Uraku, O. H. Assessment of Nephrotoxicity and Histopathological Lesions of Albino Rats Exposure to DD-Force and Baygon Insecticides. Int. J. Med. Surg. Sci., 4(4):1251-1258, 2017.

Similarly, DD-Force is an organophosphate pesticides formulated with an active ingredient dichlorvos (DDVP: 2, 2-dichlorovinyl dimethyl phosphate) for agricultural uses only and as a stomach poison (Doherty et al., 2016). A number of evidences indicate that dichlorvos in DD-Force is commonly formulated in varying concentrations (1 - 10\%) and is popularly known with a nick-name Ota-piapia in Nigeria and other countries in the tropical Africa (Abdu et al., 2016, Uthman et al., 2013, Musa et al., 2010). In Nigeria, reputable reports indicate that Ota-piapia is an unspecified insecticide/pesticide and its use is regarded as a dangerous practice since its chemical constituent is unknown (Akunyili, 2007).

Although, Ota-piapia is a vernacular of eastern Nigeria origin that suggests potency of the formulation, its indiscriminate use as domestic mosquitoes and cockroach repellant/killer, crop pesticide, or in fish and food storage is evident in Nigerian population (Musa et al.). Evidence has shown that dichlorvos has long-term toxic effects in humans (Proctor et al., 2006). Experimental studies suggest that dichlorvos causes impairment in glucose metabolism (Sarin and Gill, 1998) and neurotoxic (Abdu et al.), hepatotoxic (Uthman et al.) and genotoxic (Atherton et al., 2006) effects have been demonstrated.

However, there is a drought of reports on the health effect of DD-Force (Ota-piapia) and Baygon super in the published literature, despite the frequent indoor residential insecticide application. Therefore, this study aimed to investigate the possible renal effect of acute exposure of albino rats to DD-Force and Baygon products.

\section{METHODOLOGY}

\section{Collection of experimental Animals}

Forty-nine adult male albino rats weighing between $150 \mathrm{~g}$ to $170 \mathrm{~g}$ used in this study were purchased from the Department of Animal Science, University of Nigeria, Nsukka.

The animals were acclimatized for two weeks in laboratory condition $\left(25^{\circ} \mathrm{C}\right.$ on a $12 \mathrm{~h}$ light/dark cycle) with unrestricted access to rat chow (Vital Feeds, Jos, Nigeria) and clean water before subjected to experimentation.

\section{Collection of Insecticides}

The DD-Force (Ota-piapia) and Baygon super insecticides were purchased from a sales outlet in Abakaliki, Ebonyi State.

\section{Experimental Design}

Eight-room cabinet cupboard $2 \times 2$ square feet size with ventilation was constructed at the Animal House,
Department of Biochemistry, Ebonyi State University, Abakaliki. The cabinet cupboard was used to house the exposed animals in separate compartments during the experimental period. Following acclimatization, rats were randomly divided into 9 groups (5 rats/ group). The animals in control group (unexposed, group 9) were 20 meters away from the exposed groups. A measured volume $(2.5 \mathrm{ml})$ of either DDForce (Ota-piapia) or Baygon super was dropped per day at the centre of each cabinet room for exposure. Rats in group 1, 2, 3, and 4 were exposed in each compartment to DD-Force for 1 hour, 2 hours, 3 hours and 4 hours per day, respectively. Rats in group 5, 6, 7 and 8 were exposed in similar pattern to Baygon super for similar period of exposure, and monitored accordingly. The daily exposure in the current study lasted for 14 consecutive days. The investigation was in accordance with the Guide for the Care and Use of Laboratory Animals published by the U. S. National Institutes of Health for studies involving experimental animals.

\section{Collection of Samples}

At the end of the 14 days exposure, the animals were fasted overnight. Blood samples were collected by ocular puncture via capillary tubes into plain sample bottles. Serum was obtained after centrifugation at $1000 \mathrm{~g}$ for 10 minutes and stored at $4^{\circ} \mathrm{C}$ for analyses. Kidney samples were isolated, rinsed in cold saline and preserved in $10 \%$ buffered formalin for histopathological analysis.

\section{Biochemical analysis}

The assay for renal damage biomarkers, serumcreatinine, urea and uric acid, were carried out according to the manufacturer's procedure of the commercially available kits (Randox Laboratories, UK).

\section{Histopathological analysis}

Kidney tissues were fixed in buffered formalin, dehydrated in graded alcohol and embedded in paraffin. The sections $(5 \mu \mathrm{m})$ were stained with $\mathrm{H}$ \& $\mathrm{E}$ and examined under light microscope (Olympus BX3) by a pathologist blinded to the treatment protocol.

\section{Statistical analysis}

Statistical analysis was done using statistical program for social science (SPSS) 20.0 (SPSS, Inc. Chicago, Illinois, USA). The results of replicate measurements were presented as means \pm standard error of mean (SEM). One way analysis of variance (ANOVA) was carried out followed by Tukey test for the post-hoc treatment. A value of $p<0.05$ was considered significant. 
Nwankwo, V. O., Uraku, A. J., Famurewa, A. C. \& Uraku, O. H. Assessment of Nephrotoxicity and Histopathological Lesions of Albino Rats Exposure to DD-Force and Baygon Insecticides. Int. J. Med. Surg. Sci., 4(4):1251-1258, 2017.

FIGURE. 1. Effect of exposure to DD-Force (Ota-piapia) and Baygon super insecticides on serum creatinine levels in albino rats. Values are expressed as mean \pm SEM $(n=5)$.

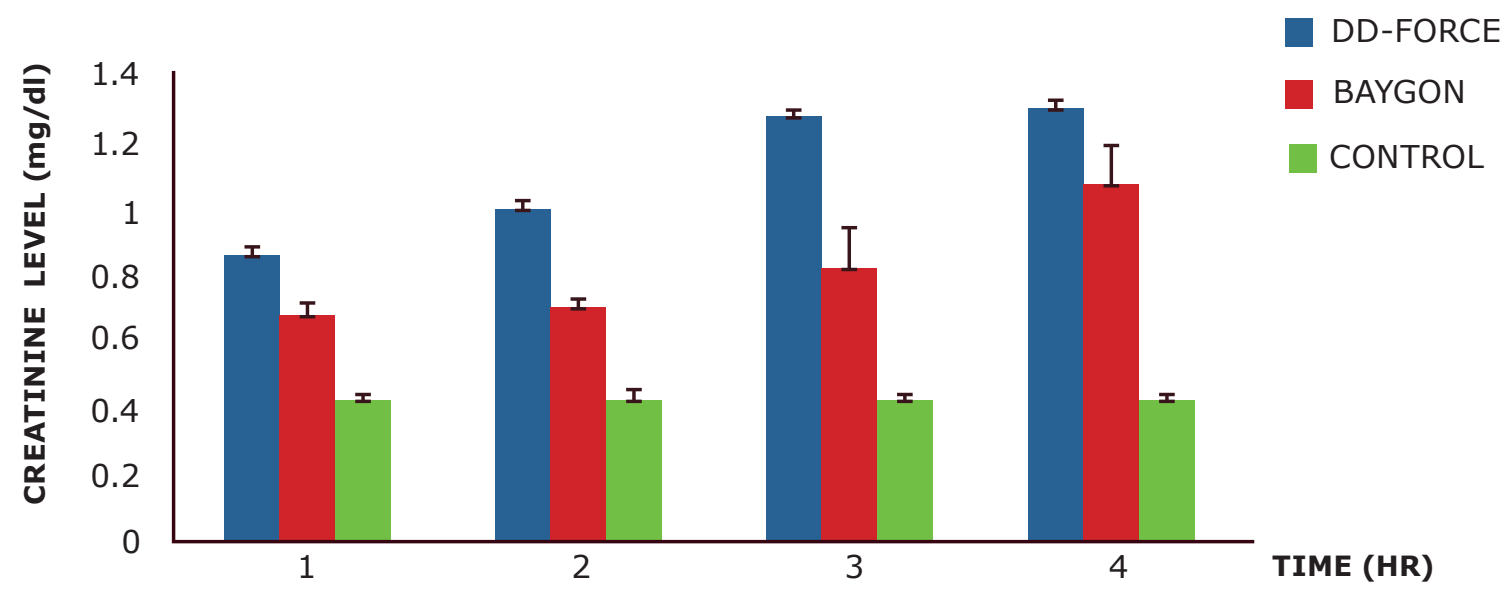

FIGURE. 2. Effect of exposure to DD-Force (Ota-piapia) and Baygon insecticides on serum uric acid levels in albino rats. Values are expressed as mean $\pm \operatorname{SEM}(n=5)$.

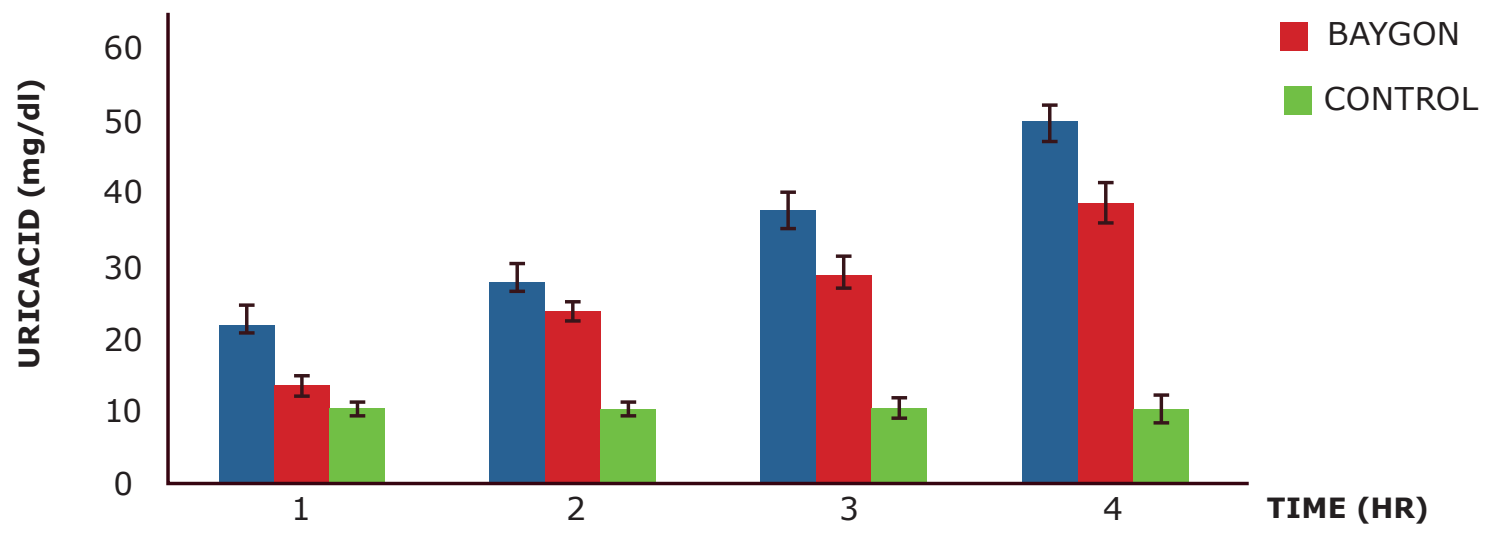

FIGURE. 3. Effect of exposure to DD-Force (Ota-piapia) and Baygon insecticides on serum urea levels in albino rats. Values are expressed as mean $\pm \operatorname{SEM}(n=5)$.

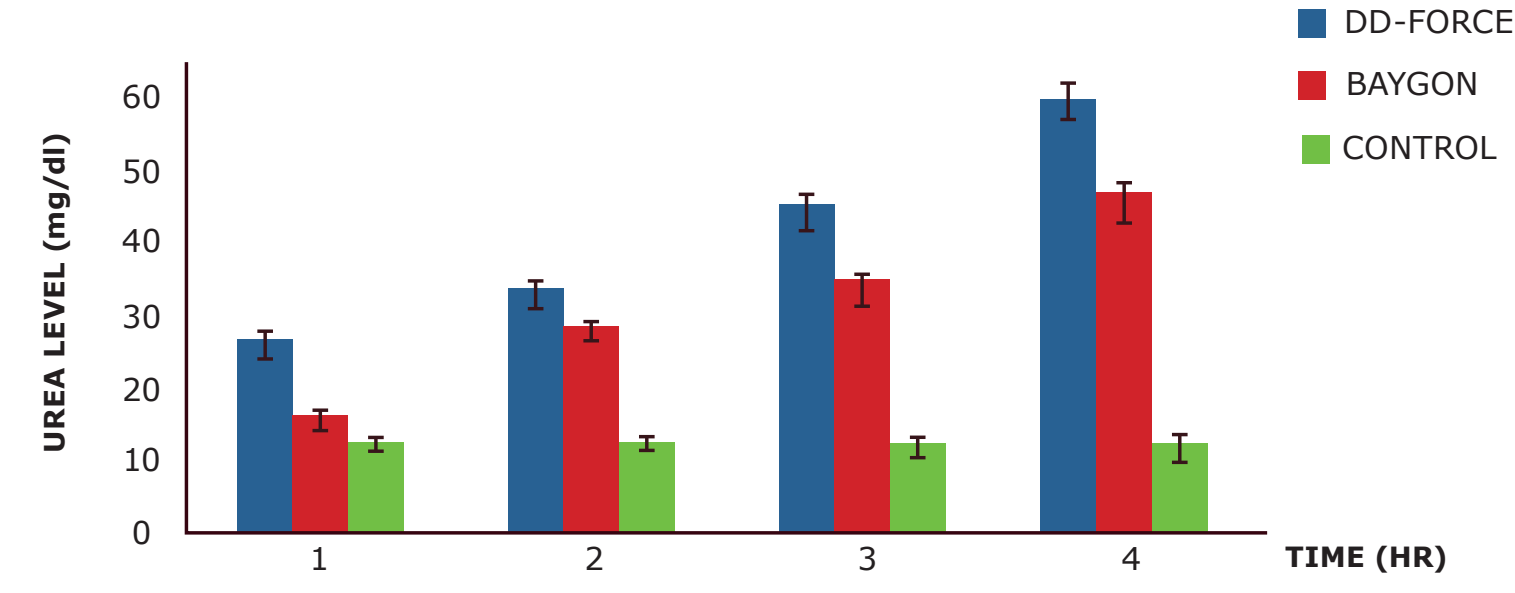


Nwankwo, V. O., Uraku, A. J., Famurewa, A. C. \& Uraku, O. H. Assessment of Nephrotoxicity and Histopathological Lesions of Albino Rats Exposure to DD-Force and Baygon Insecticides. Int. J. Med. Surg. Sci., 4(4):1251-1258, 2017.

FIGURE.4. Photomicrograph of the normal kidney architecture of control rats (H\&E, x60), showing normal glomerulus (NG) and normal tubules (NT).

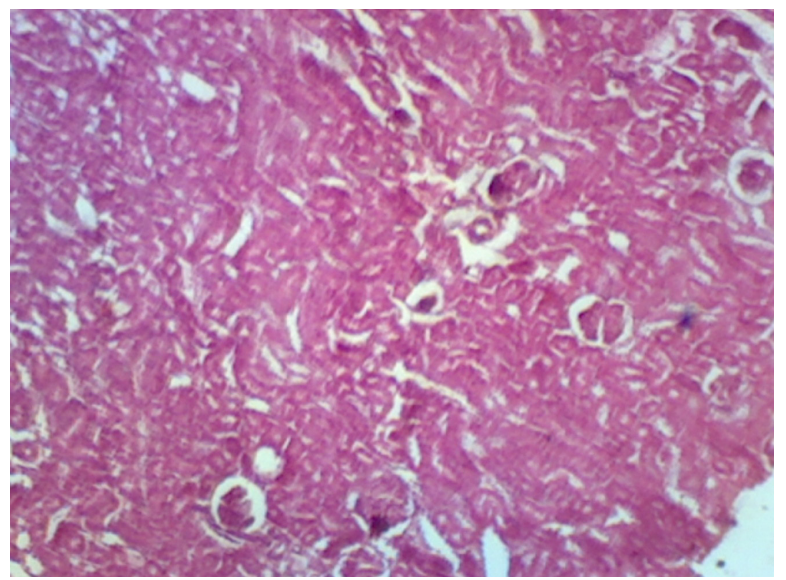

FIGURE.5a. Photomicrograph of rat kidney section exposed to DD-Force (Ota-piapia) for 1 hour (H\&E, x60), showing focal area of congested vessels (FACV), distortion of the glomeruli (DG) and renal perfusion.

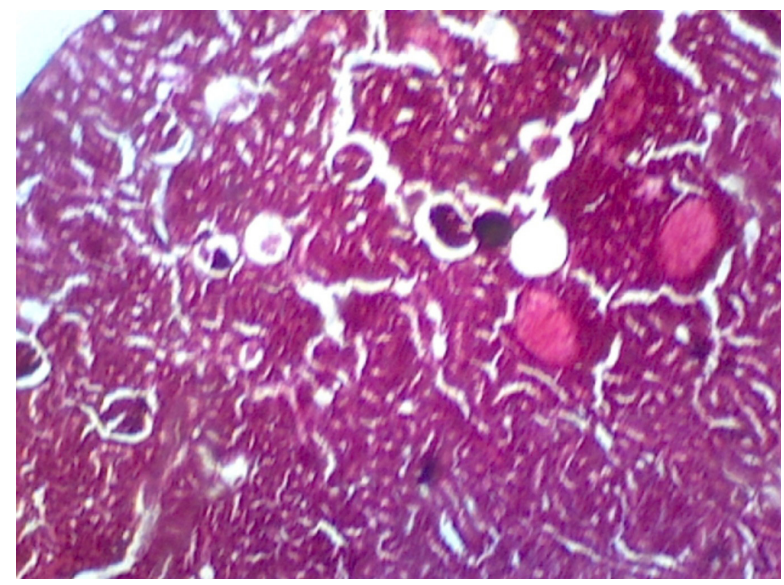

FIGURE.5b. Photomicrograph of rat kidney section exposed to Baygon for 1 hour (H\&E, x60), showingmild fatty change (MFC), mild distortion, and mild infiltration of inflammatory cells (MIIC).

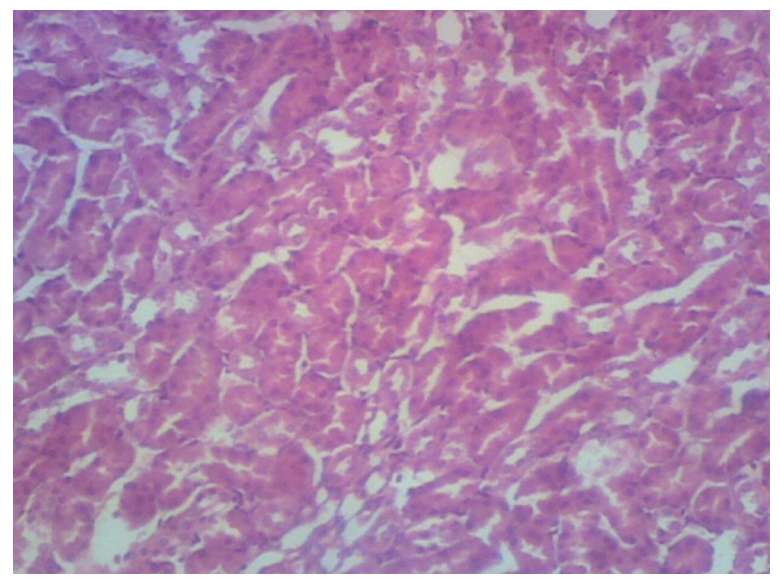

\section{RESULTS}

\section{Effect of DD-Force (Ota-piapia) and Baygon on serum creatinine}

The effect of exposure to DD-Force (Ota-piapia) and Baygon super on serum creatinine levels of rats in group 1 to 8 and control group (unexposed) are shown in Figure 1. Experimental exposure of rats to the insecticides, DD-Force and Baygon super, significantly increased at $p<0.05$ serum creatinine levels in a duration-dependent manner, compared to control. However, result showed that DD-Force comparatively and significantly $(p<0.05)$ raised serum creatinine levels than in Baygon super after separate 2 and 3 hours of exposures per day for 14 consecutive days.

FIGURE.6a. Photomicrograph of rat kidney section exposed to DD-Force for 2 hours (H\&E, x60), showing focal area of degeneration (FADT) with congestion of some renal vessels (CRV).

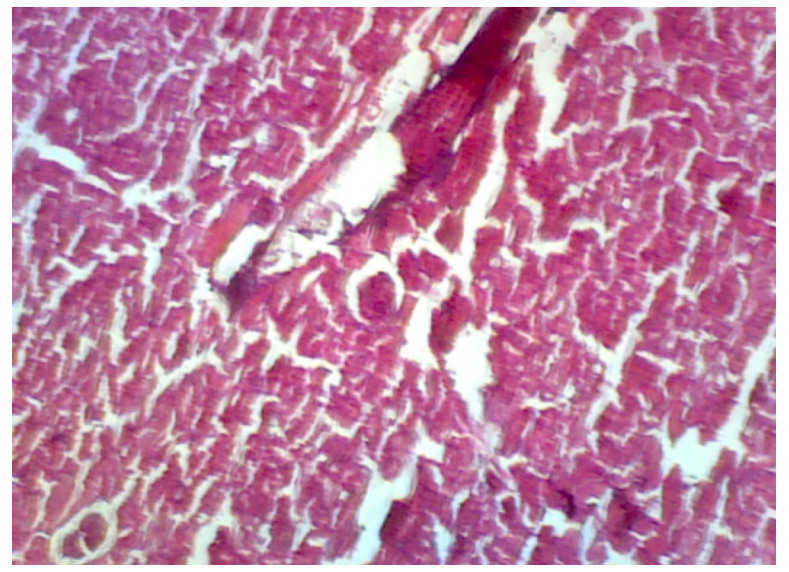

FIGURE.6b. Photomicrograph of rat kidney section exposed to Baygon for 2 hours (H\&E, x60), showingintrarenal hemorrhage (IRH), mild distortion of renal architecture (MDRA) and differential perfusion (DP) of the tubular cells.

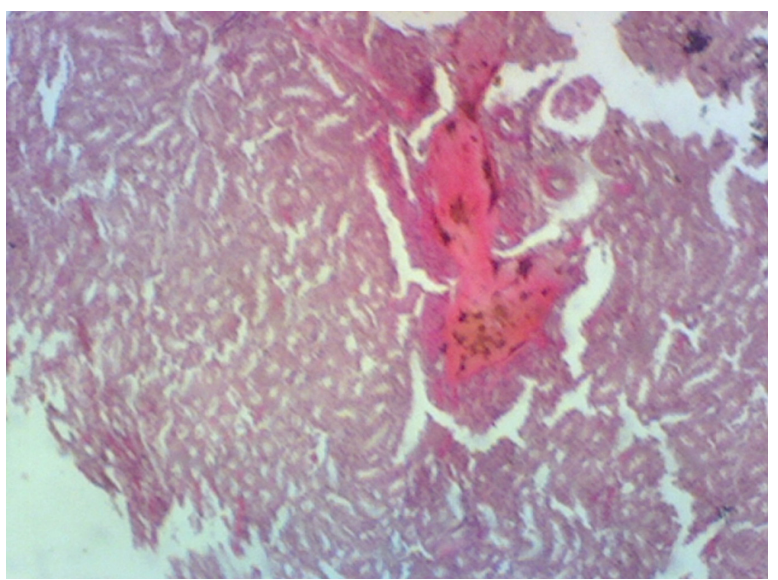


Nwankwo, V. O., Uraku, A. J., Famurewa, A. C. \& Uraku, O. H. Assessment of Nephrotoxicity and Histopathological Lesions of Albino Rats Exposure to DD-Force and Baygon Insecticides. Int. J. Med. Surg. Sci., 4(4):1251-1258, 2017.

FIGURE.7a. Photomicrograph of rat kidney section exposed to DD-Force (Ota-piapia) for 3 hours (H\&E, x60), showing mild distortion of the renal tissues (MDRT), congestion of some vessels (CV) and tubular and glomerular perfusion.

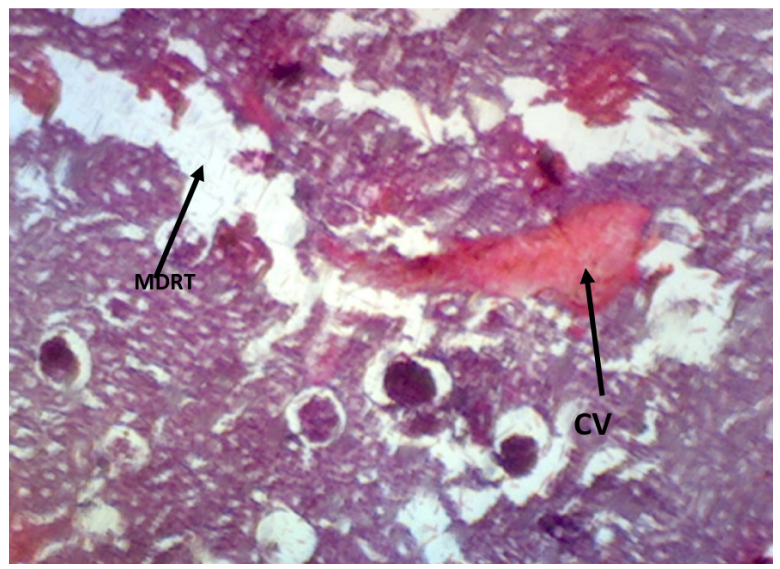

FIGURE.7b. Photomicrograph of rat kidney section exposed to Baygon for 3 hours ( $H \& E, x 60)$, showing severe fatty changes (SFC) and coagulative necrosis of the renal tissues (CNRT) with ghost-like remnants.

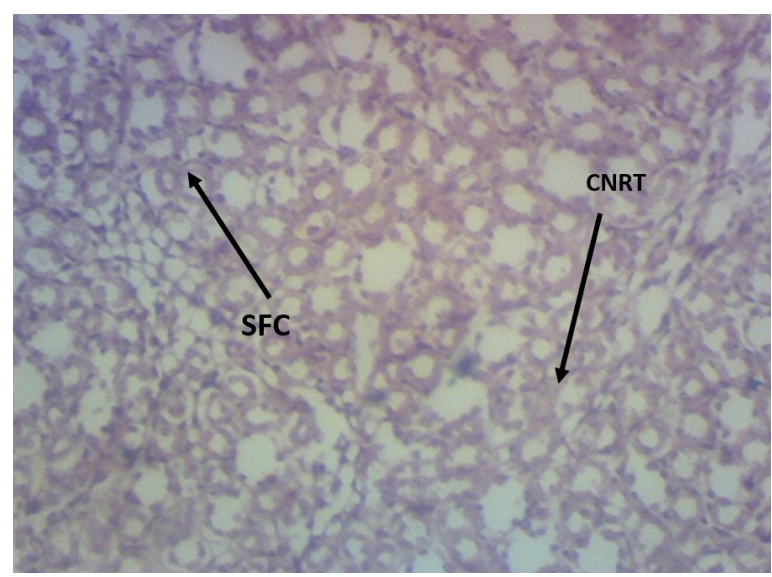

Effect of DD-Force (Ota-piapia) and Baygon on serum uric acid

Figure 2 depicts the effect of exposure to DDForce (Ota-piapia) and Baygon super on serum uric acid levels of rats in group 1 to 8 and control group (unexposed). Serum uric acid level significantly increased in rats exposed to DD-Force and Baygon in a duration-dependent manner, compared to control $(p<0.05)$. However, DD-Force markedly increased uric acidlevels than in Baygon after 4 hours exposure per day for 14 consecutive days.

Effect of DD-Force (Ota-piapia) and Baygon on serum urea

Figure 3 represents the effect of exposure to DDForce (Ota-piapia) and Baygon on serum urea levels
FIGURE.8a. Photomicrograph of rat kidney section exposed to DD-force (Ota-piapia) for 4 hours (H\&E, x60), showing focal area of degenerative changes (FADC), loss of renal tissues (glomeruli) and hemorrhage $(\mathrm{H})$.

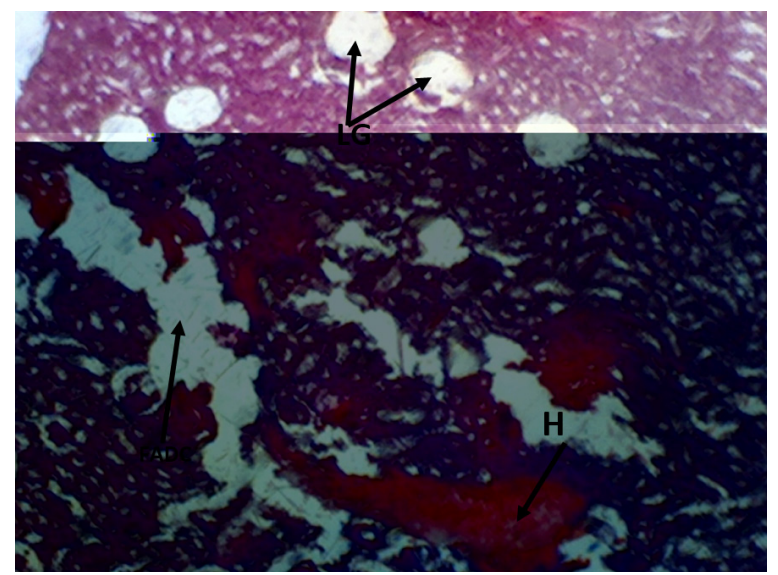

FIGURE.8b. Photomicrograph of rat kidney section exposed to Baygon for 4 hours ( $H \& E, x 60)$, showing extensive fatty changes (EFC) with necrosis of the renal tissue (NRT).

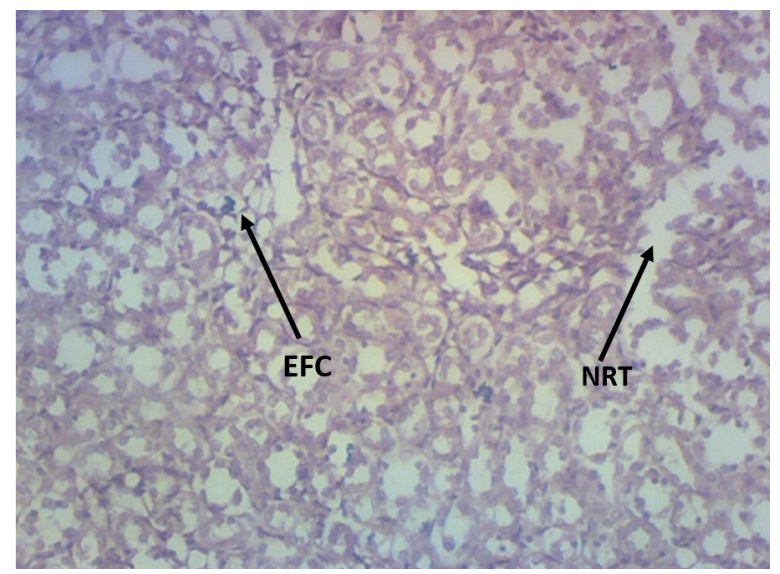

of rats in group 1 to 8 and control group (unexposed). Serum urea level significantly increased at $p<0.05$ in rats exposed to DD-Force and Baygon in a durationdependent manner, compared to control.

\section{Effect of DD-Force (Ota-piapia) and Baygon on renal histology}

In the current study, histopathological changes in kidneyfor control and exposed animals were evaluated and are presented in Figure 4 to 8.

The microscopical examination of renal tissues of the control group revealed normal renal glomeruli surrounded by capsule and normal proximal and distal convoluted tubules (Figure 4).

However, the kidney tissues confirmed the biochemical observations by duration-dependent 
Nwankwo, V. O., Uraku, A. J., Famurewa, A. C. \& Uraku, O. H. Assessment of Nephrotoxicity and Histopathological Lesions of Albino Rats Exposure to DD-Force and Baygon Insecticides. Int. J. Med. Surg. Sci., 4(4):1251-1258, 2017.

renal disruption/injury in rats exposed to either DDForce or Baygon insecticide. Histopathological lesions such as congested vessels, distortion of the glomeruli (DG), infiltration of inflammatory cells, and renal perfusionwere observed. At 3 to 4 hours of exposure to DD-Force, severe fatty changes and coagulative necrosis of the renal tissues, intertubular hemorrhage were observed in the renal sections ofexposed rat groups.

\section{DISCUSSION}

The growth and civilization have increased human exposure to environmental pollutants that may have acute and chronic adverse effects on health. Synthetic chemicals in pesticides and/or insecticides may contribute long-term effects in the environment. In homes, humans are concomitantly exposed to insecticides whose toxicity profiles have not been delineated. DD-Force contains dichlorvos that is classified by the WHO as a highly hazardous chemical (Class Ib) (WHO, 1992) while Baygon is a formulation of proporxur, dichlorvos, and cyfluthrin (Yassin \& AlShanti; Institóris et al.), which accumulate in human and fish tissues to cause toxic effects (Tsitsimpikoua et al., 2013, Begum).

In this study, we have evaluated renal and histopathological effects of two indoor insecticides DD-Force (dichlorvos) (known as Ota-piapia in Nigeria) and Baygon (propoxur) via air-fume exposure in male albino rats for 14 consecutive days.

The results of the acute exposure clearly show that DD-Force and Baygon have potentials to promote renal damage.

This was evident in the study by significant increases in serum levels of creatinine, urea and uric acid in a duration-dependent pattern (Figure 1, 2 and 3). Creatinine, urea and uric acid are known biochemical markers of acute and chronic nephrotoxicity (Naggayi et al., 2015). Thus, serum creatinine and urea concentrations are often considered as reliable predictors of renal function (Naggayi et al.; Yaman \& Balikci, 2010).

Creatinine is a product of endogenous sources of tissue creatine breakdown and excreted in the kidney. Increase in serum creatinine level is indicative of parenchyma injury and glomerular filtration rate reduction is often associated with increases in serum urea and uric acid (Okokon et al., 2011, Begum). Elevation of the serum renal parameters observed in the present study may be explained by damage to parenchyma architecture and decrease in filtration rate of the kidneyin response to insecticide exposures.

There is abundant information on the neurotoxic effects of propoxur and dichlorvos, active ingredients in Baygon and DD-Force respectively. However, their possible nephrotoxic effects are sparsely reported. Tsitsimpikou et al.(2013) show that high and low doses of propoxur induced focal inflammation and fibrosis in the liver and kidneys of rabbits. The study by Igwenyi et al.(2014) reported hepatotoxic effect of acute exposure of rats to Baygon insecticide. Dichlorvos, the chemical insecticide in DD-Force is metabolized by the liver and the metabolites, dimethylphosphate and dichloroacetaldehyde are excreted by the kidney (Abdu et al.).

It is the active pesticide ingredient in the local formulation of Ota-piapia commonly used in Nigeria, and its hepatotoxic and neurotoxic potentials have been reported in previous studies (Uthman et al., Abdu et al.). To our knowledge, there are no reports on nephrotoxicity of dichlorvosor DD-Force. The current study has demonstrated acute nephrotoxic effect of DD-Force in albino rats.

However, extensive studies suggest that organophophate pesticides, of which dichlorvos is one, induces disturbances in redox processes, causing enhancement of lipid peroxidation and oxidative stress in organs, including the kidney in fish, rats and humans (Mundhe and Pandit, 2014; LukaszewiczHussain, 2010; Rastogi et al., 2009).

Although, the current study fails to assess oxidative stress status, the imbalance in favour of free radicals may contribute to the renal damage and histopathological lesions resulting in marked elevation of creatinine, urea and uric acid in DD-Force-exposed rats in a duration-dependent manner in this study. It is noteworthy that DD-Force demonstrated more pronounced nephrotoxicity than the effect due to exposure to Baygon. Our results were confirmed by the histopathological alterations observed in renal tissue. As shown by steep increase in renal markers with increase in duration of exposure, major damage to renal architecture were observed after 3 to 4 hours of exposure.

\section{CONCLUSION}

The current study suggests that Baygon, a common domestic insecticide and DD-Force, a dichlorvos insecticide known as Ota-piapia in Nigeria, have potentials to induce nephrotoxicity and alter architectural integrity of renal tissue in rats. We found that DD-Force induced renal damage more than Baygon.

The implication of our findings is that continuous exposure to these insecticides may impart deleterious effect on the kidney. It is therefore a matter of public health significance to control exposure to the insecticide residues in homes. 
Nwankwo, V. O., Uraku, A. J., Famurewa, A. C. \& Uraku, O. H. Assessment of Nephrotoxicity and Histopathological Lesions of Albino Rats Exposure to DD-Force and Baygon Insecticides. Int. J. Med. Surg. Sci., 4(4):1251-1258, 2017.

Nwankwo, V. O., Uraku, A. J., Famurewa, A. C. \& Uraku, O. H. Evaluación de la nefrotoxicidad y lesiones histopatológicas tras la exposición de ratas Albino a los insecticidas DD-Force y Baygon Int. J. Med. Surg. Sci., 4(4):1251-1258, 2017.

RESUMEN: Aunque los estudios sugieren efectos adversos de los pesticidas, la exposición humana a los insecticidas en los hogares está aumentando y los informes sobre sus efectos sobre la salud son limitados. Este estudio investigó los efectos nefrotóxicos de los insecticidas órgano fosfato y carbamato, DD-Force y Baygon, en ratas albinas. Cuarenta y cinco ratas albinas divididas en grupos fueron expuestas a DD-Force (diclorvos) o Baygon (propoxur) insecticidas de interior en cajas de madera en una duración de exposición separada de 1, 2, 3 y 4 horas / día durante 14 días consecutivos. Muestras séricas y de tejido renal obtenidas después del sacrificio se utilizaron para determinar los marcadores de daño renal y el análisis histopatológico, respectivamente. La exposición de las ratas a los insecticidas mostró aumentos significativos dependientes de la duración $(p<0.05)$ en los niveles séricos de urea, ácido úrico y creatinina en comparación con el control. Sin embargo, las ratas expuestas al insecticida DD-Force indujeron niveles significativamente más altos de urea, ácido úrico y creatinina en comparación con Baygon $(p<0.05)$. Se observaron lesiones histopatológicas en ratas expuestas a los insecticidas, particularmente en la duración de exposición de 3 o 4 horas/día. Estos hallazgos sugieren que la exposición aguda a DD-Force y Baygonis nephrotóxico y puede inducir daño renal en ratas.

PALABRAS CLAVE: insecticidas; DD-Force; Baygon; exposición; daño renal.

\section{REFERENCIAS}

AAbdu, I.T., Adamu, L.H., Modibbo, M.H. \& Yusuf, A.A. Effect of dichlorvos on histoarchitecture of the cerebral blood vessels in adult wistar rats. Journal of Neurobehavioral Sciences., 3(1):7-12, 2016.

Akunyili, D (2007). Otapiapia' not registered with NAFDAC in Daily Triumph Newspaper. [Available at: http://www.triumphnewspapers.com/].

Aldana, L., Tsutsumi, V., Craigmill, A., Silveira, M.I. \& González de Mejía, E. alpha-Tocopherol modulates liver toxicity of the pyrethroid cypermethrin. Toxicol. Lett., 125(1-3):107-16, 2001.

Atherton, K.M., Williamson, F.M., Jameson, S.J. \& Mutch, E.M. DNA damage by dichlorvos and repair profiles in human lymphocytes, in vitro. Toxicology., 226(1):53, 2006.

Banerjee, B.D., Seth, V., Bhattacharya, A., Pasha, S.T. \& Chakraborty, A.K. Biochemical effects of some pesticides on lipid peroxidation and free-radical scavengers. Toxicol. Lett., 107(1-3):33-47., 1999.

Begum, G. Carbofuran insecticide induced biochemical alterations in liver and muscle tissues of the fish Clarias batrachus (linn) and recovery response. Aquat. Toxicol., 66(1):83-92, 2004.

Bohmont, B. L. (1990). The Students' Pesticide Users Guide. 8th edition. Prentice-Hall Inc., London, 170-221.

Doherty, V.F., Ladipo, M.K., Aneyo, I.A., Adeola, A. \& Odulele, W.Y. Histopathological alterations, biochemical responses and acetylcholinesterase levels in Clariasgariepinusas biomarkers of exposure to organophosphates pesticides. Environ. Monit. Assess., 188(5):312, 2016.
Igwenyi, I.O., Aboh, N., Nwachukwu, N., Ibiam, U.A., Offor, C.E., Aja, P.M. \& Agbafor, K.N. Effect of baygoninsecticide on the activities of total, alkaline and acid phosphatases of selected tissues of albino rats. J. Pharm. Biol. Sci., 9(3):41-3, 2014.

Institóris, L., Papp, A., Siroki, O., Banerjee, B.D. \& Dési, I. Immuno- and neurotoxicological investigation of combined subacute exposure with the carbamate pesticide propoxur and cadmium in rats. Toxicology., 178:161-73, 2002.

Kolawole, O.T \& Asaolu, O. S. Mothers' socioeconomic differentials and management of malaria in Nigeria. SAGE Open: 1- 9, 2016.

Lukaszewicz-Hussain, A. Role of oxidative stress in organophosphate insecticide toxicity - Short review. Pest. Biochem. Physiol., 98: 145-50, 2010.

Mundhe, A.Y. \& Pandit, S.V. Assessment of Toxicity of Monocrotophos in Freshwater Bivalve, Lamellidens marginalis, Using Different Markers. Toxicol. Int., 21(1): 51-6, 2014.

Musa, U., Hati, S.S., Mustapha, A. \& Magaji, G. Dichlorvos concentrations in locally formulated pesticide (Ota-piapia) utilized in northeastern Nigeria. Sci. Res. Essay., 5(1): 49-54, 2010.

Naggayi, M., Mukiibi, N. \& Iliya, E. The protective effects of aqueous extract of Carica papaya seeds in paracetamol induced nephrotoxicity in male wistar rats. Afr. Health. Sci., 15(2): 598-605, 2015.

Ngoula, F., Watcho, P., Bouseko, T.S., Kenfack, A., Tchoumboué, J. \& Kamtchouing, P. Effects of propoxur on the reproductive system of male rats. Afr. J. Reprod. Health., 11(1):125-32, 2007. 
Nwankwo, V. O., Uraku, A. J., Famurewa, A. C. \& Uraku, O. H. Assessment of Nephrotoxicity and Histopathological Lesions of Albino Rats Exposure to DD-Force and Baygon Insecticides. Int. J. Med. Surg. Sci., 4(4):1251-1258, 2017.

Okokon, J.E., Nwafor, P.A., \& Noah, K. Nephroprotective effect of Croton zambesicus root extract against gentimicin-induced kidney injury. Asian. Pac. J. Trop. Med.,4(12):969-72, 2011.

Proctor, S.P., Heaton, K.J., Heeren, T., \& White, R.F. Effects of sarin and cyclosarin exposure during the 1991 Gulf War on neurobehavioral functioning in US army veterans. Neurotoxicology., 27(6):9319,2006.

Rastogi, S.K., Satyanarayan, P.V., Ravishanker, D., \& Tripathi, S.A study on oxidative stress and antioxidant status of agricultural workers exposed to organophosphorus insecticides during spraying. Indian. J. Occup. Environ. Med., 13(3): 131-34, 2009.

Rekha, S.R. \& Sajad, H. Histopathological effects of pesticide-cholopyrifos on kidney in albino rats. Int. J. Res. Med. Sci., 1(4):465-75, 2013.

Sarin, S., \& Gill, K.D. Dichlorvos induced alterations in glucose homeostasis: Possible implications on the state of neuronal function in rats. Mol. Cell. Biochem., 199:87-92, 1999.

Tsitsimpikou, C., Tzatzarakis, M., Fragkiadaki, P., Kovatsi, L., Stivaktakis, P., Kalogeraki, A., Kouretas, D. \& Tsatsakis, A.M. Histopathological lesions, oxidative stress and genotoxic effects in liver and kidneys following long term exposure of rabbits to diazinon and propoxur. Toxicology., 10;307:109-14, 2013.

Uthman, G.S., Aminu, N.A., Musa, H.A., Ahmad, M.A., Musa, A.B., Wazis, H.C., Zezi. A. \& Timothy, S.Y. Biochemical and Histopathologic Changes in Liver of Albino Rats Exposed to 1\% Dichlorvos Pesticide at Sub-Acute Period. J. Pharm. Biomed. Sci., 3(2): 1-6, 2013.

International Programme on Chemical Safety, The WHO recommended classification of pesticides by hazard and guidelines to classification 19941995, UNEP/ILO/WHO 1994.
Yaman, I. \& Balikci, E. Protective effects of nigella sativa against gentamicin-induced nephrotoxicity in rats. 62: 183-190, 2010. Exp. Toxicol. Pathol., 62(2):183-90, 2010.

Yassin, M.M, \& Al-Shanti, T.A. Effect of pesticides on kidney function and serum protein profile of farm workers in Gaza Strip. AMBS., 2(1): 21-7, 2015.

\section{Corresponding author:}

Uraku, Anayo. Joseph.

Department of Biochemistry, Ebonyi State

University, Abakaliki, Nigeria

Phone: (+234) 8068073037

E-mail: urakuaj@yahoo.com,urakuaju@gmail.com.

Conflict of Interest. the authors have decleared that there is no competing interest existing.

Financial Interest: None.

Authors' contributions: This work was carried out in collaboration between all Authors. Author NVO designed the Study and managed the analysis of the study and the bench work. Author UAJ wrote the protocol, performed the statistical Analysis while Author FAC wrote the first draft of the manuscript and managed the literature search. All authors read and approved the final manuscript

Acknowledgements: None.

Receipt: $13-12-2017$

Acceptance: 10-01-2018 